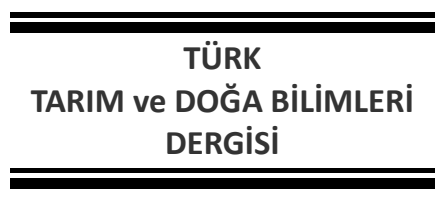

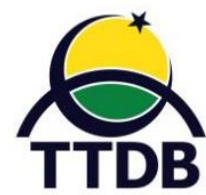

www.dergipark.gov.tr/turkjans

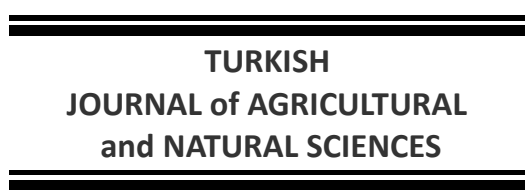

Araştırma Makalesi

\title{
Yüzey Aktif Madde ile Modifiye Edilmiş Atık Yer Fıstığı Kabuğunun Tekstil Boyası Biyosorpsiyonu Kapasitesinin Belirlenmesi
}

\author{
Ülküye Dudu GÜL ${ }^{1,2^{*}}$, Yüksel YILDIZ ${ }^{3}$ \\ ${ }^{1}$ Sağıık Hizmetleri MYO, Bilecik Şeyh Edebali Üniversitesi, Bilecik \\ ${ }^{2}$ Biyoteknoloji Uygulama ve Araştırma Merkezi, Bilecik Şeyh Edebali Üniversitesi, Bilecik \\ ${ }^{3}$ Moleküler Biyoloji ve Genetik Bölümü, Fen Edebiyat Fakültesi, Bilecik Şeyh Edebali Üniversitesi, Bilecik \\ *Sorumlu yazar: ulkuyedudu.gul@bilecik.edu.tr; ulkuyedudugul@gmail.com
}

Geliş Tarihi: 11.02.2019 Düzeltme Geliş Tarihi: 14.02.2020 Kabul Tarihi: 06.05.2020

Öz

Tekstil endüstrisinin gelişimi ülke ekonomisini olumlu yönde etkilemektedir, öte yandan su kirliliği gibi bazı çevre problemlerine neden olmaktadır. Tekstil boyaları sucul ortamlar için en önemli kirleticilerdir. Bu çalışmanın amacı atık yer fıstığı kabuğunun boya ile kirlenmiş sıvıların arıtımında biyosorbent olarak kullanılabilme potansiyelini incelemektir. Biyosorpsiyon kapasitesini arttırmak için yer fıstığı kabuğu Hegzadesiltrimetil amonyum bromür (HTAB) isimli yüzey aktif madde kullanılarak modifiye edilmiştir. Boya biyosorpsiyonuna yer fıstığı kabuğu modifikasyonunda kullanılan yüzey aktif madde derişimi, sıcaklık, $\mathrm{pH}$ ve temas süresi etkisi araştırılmıştır. Bu çalışmadan elde edilen bulgulara göre modifiye edilmemiş ve $2 \mathrm{mM}$ yüzey aktif madde ile modifiye edilmiş yer fıstığı kabuğunun tekstil boyası giderimi sırasıyla \%30.60 ve \%97.48 olarak saptanmıştır. Araştırma sonuçları yüzey aktif madde ile modifiye edilmiş yer fıstığı kabuğunun modifiye edilmemişe oranla 3 kat daha fazla boya biyosorpsiyonu gerçekleştirdiğini göstermiştir. Bu çalışmadan elde edilen sonuçlara göre modifiye yer fıstığı kabuğu tekstil boyası ile kirlenmiş suların artımında ucuz ve çevre dostu bir biyosorbent olarak kullanılabilecektir.

Anahtar Kelimeler: Biyosorpsiyon, Tekstil boyası, Yer fıstığı kabuğu, Yüzey aktif madde

\section{Determination of Textile Dye Biosorption Capacity of Waste Peanut Shell Modified with Surface Active Agent}

\begin{abstract}
Development of textile industry effects the economy of the country positively, but also causes some environmental problems such as water pollutions. Textile dyes are the most important pollutants for aquatic environment. The aim of this study is to investigate the potential of using peanut hard shell as a biosorbent in the treatment of contaminated water. To increase the biosorption capacity, peanut shell was modified using surface active agent called Hexadecyltrimethylammonium bromide (HTAB). The effect of surface active agent concentration on peanut shell modification, temperature, $\mathrm{pH}$ and contact time was investigated. The results obtained from this study showed that the dye removal of unmodified and modified with $2 \mathrm{mM}$ surface active agent peanut shell was removed as $30.60 \%$ and $97.48 \%$, respectively. The results of the study showed that the surface active agent modified peanut shell performed 3 times more dye biosorption than unmodified one. According to the results obtained from this study, modified peanut shell can be used as a cheap and environmentally friendly biosorbent in the treatment of contaminated water with textile dye.
\end{abstract}

Keywords: Biosorption, Textile Dye, Peanut Shell, Surface Active Agent 
Giriş

Tekstil endüstrisi diğer endüstrilere göre çıkış suyu kompozisyonu göz önüne alındığında çevreyi en çok kirleten endüstridir. Boyama esnasında boyanın yaklaşık \%10-15'nin atık suya geçtiği bilinmektedir (Gomez ve ark., 2007). Tekstil endüstrisinde ürünlerin her kg'ı başına yaklaşık olarak 40-65 L atık su oluştuğu bildirilmiştir (Manu ve Chaudhari, 2002). Yillık olarak yaklaşık 280.000 ton boyalı atık su dünya genelinde alıcı ortamlara bırakılmaktadır (Mass ve Chaudhari, 2005). Remazol Black B isimli boya anyonik karakterli reaktif azo boyalar grubunda yer almaktadır. Anyonik boyalar Türkiye'de boyama sanayinde en büyük pazar payına sahiptir (Arslan Alaton ve Teksoy, 2007). Günümüzde reaktif boyalar parlak renk oluşturduğu için tekstilde en yaygın kullanılan boya türleridir. Azo boyaların mutajenik, karsinojenik ve toksik özelliklere sahip olduğu bilinmektedir (Seesuriyachan ve ark., 2007).

Tekstil endüstrisinde boyalarla birlikte yüzey aktif maddeler de kullanılmaktadır. Yüzey aktif maddeler boya dağılımını düzenleyici ve çözücü özelliklerinden dolayı boyama işleminde ıslatıcı, dağıtıcı ve düzgün boyama yapıcı olarak kullanılmaktadır (Kartal ve Akbaş, 2005). Düzgün boyama yapıcı ajanlar tekstil ürününe tutunmada boya ile yarışa girerek boyanın kumaşa ilgisini azaltarak boyanın düzgün bir şekilde tekstil ürünü üzerinde yayılmasını sağlamaktadır (Bagha ve ark., 2007). Bir alkil amonyum bromürü olan Hegzadesiltrimetil amonyum bromür (HTAB) katyonik karakterli yüzey aktif maddeler içinde yer alır. Bu yüzey aktif maddelerin katyonik özelliğe sahip olmalarının nedeni ise yapılarında bulunan azot atomlarıdır. Yapılarında hem amin hem de kuaterner amonyuma sahip çok çeşitli yüzey aktif maddeler bulunmaktadır. Boyama işleminde kullanılan boyalar gibi yüzey aktif maddeler de tekstil atık suları ile birlikte yer altı ve yer üstü sularına bırakılmaktadır. Boya ve yüzey aktif madde içeren atık suların ulaştıkları alıcı ortama olumsuz etkilerinin yanı sıra; insan bünyesine ulaşması ile böbrek fonksiyonlarına, üreme sistemine, karaciğer, beyin ve merkezi sinir sistemine sert tahribatlara neden olduğu bildirilmiştir (Özcan ve Özcan, 2005).

Tekstil endüstrisi başta olmak üzere endüstriyel atık suları alıcı ortamlara bırakılmadan önce arıtılmalıdır. Fiziksel, kimyasal ve biyolojik arıtım yöntemleri olmak üzere 3 çeşit atık su arıtım yöntemi bulunmaktadır. Biyolojik arıtım diğer arıtım yöntemlerine göre daha ekonomik ve çevre dostu olduğu için avantajlıdır. Biyolojik materyal kullanılarak adsorpsiyon mekanizması ile atık su artımı biyosorpsiyon olarak ifade edilmektedir. Son yıllarda yapılan çalışmalar ucuz ve çevre dostu biyoteknolojik bir yöntem olan biyosorpsiyon yöntemi ile atık su artımı üzerine odaklanmıştır (Bilen ve Yıldırım, 2017). Biyosorpsiyonda kullanılan adsorbana ise biyosorbent adı verilmektedir. Biyosorpsiyon yönteminde maliyeti düşürmek amacıyla ucuz biyosorbentlerin kullanımı önem arz etmektedir. Çeşitli tarımsal ürünlere ait atıkların ucuz ve etkin biyosorbent olarak kullanımına yönelik çalışmalara da ilgi artmıştır (Chaleshtori ve ark., 2017).

Yağ içeriği açısından değerli bir bitki olan yer fıstığı (Arachis hypogaea) baklagiller familyasına ait olup, tek yıllık bir bitki özelliğindedir. Dünya'daki bitkisel yağ üretiminde yer fıstığı ilk üç sırada yer almaktadır (Şahin, 2014). Yer fıstığı ülkemizde ise daha çok çerez bitkisi olarak tanınmakta ve kullanılmaktadır (Taşar ve ark., 2015). Bileşiminde \%45-55, \%20$25, \% 16-18$ ve $\% 5$ oranlarında sırasıyla protein, karbonhidrat ve mineral madde içeren yer fistığı hem insan hem de hayvan beslenmesinde kullanılabilecek önemli bir besin kaynağıdır (Kadiroğlu, 2014). Dünya genelinde yer fıstığı üretim miktarı yıllık 18.54 milyon ton olarak bildirilmiştir (Taşar ve ark., 2015). Bu üretimin \%33'ü Hindistan, \%26'sı Çin, \%24'ü Afrika ve $\% 10^{\prime} u$ ise Kuzey Amerika'da gerçekleşmektedir. Türkiye'de ise yıllık yer fıstığı üretimi ortalama 70 bin ton'dur. Türkiye'de yer fıstığı üretiminin \%95'i Akdeniz bölgesinde gerçekleşmektedir. Dünya'da ve Türkiye'de atık yer fıstığı kabuğu potansiyeli ise sırasıyla 24,50 ve 6,49 milyon ton/yıl'dır (Taşar ve ark., 2015). Bu yüksek potansiyel oranlarından dolayı yer fıstığı kabuğu tarımsal ürünlere ait atıklar arasında önemli bir yere sahiptir (Bilir, 2009).

Katyonik yüzey aktif maddelerin çeşitli özelliklerdeki yüzeyler tarafından güçlü bir şekilde Adsorplanabildikleri için yüzey modifikasyonlarında yaygın olarak kullanıldığı bilinmektedir (Gül, 2019). Ancak, literatürde yüzey aktif maddelerle modifiye edilmiş atıkların 
biyosorbent olarak kullanımına yönelik sınırlı sayıda çalışma bulunmaktadır.

Bu çalışmada Türkiye'de yaygın olarak kullanılan Remazol Black B isimli tekstil boyasının sulu ortamlardan gideriminde Hegzadesiltrimetil amonyum bromür (HTAB) isimli yüzey aktif madde ile modifiye edilmiş atık yer fıstığı kabuğunun kullanılabilirliği araştırılmıştır. Yer fıstığı kabuğu katı atık olarak kabul edildiği için elde edilebilirliği kolaydır ve fazla miktarda bulunabilmektedir. Bu çalışmanın ikincil amacı ise bir katı atığın atık su arıtımında ucuz bir biyosorbent olarak kullanılabilirliğini incelemektir.

\section{Materyal ve Metot}

\section{Biyosorbent hazırlanması}

Atık yer fıstığı kabuğu toplandıktan sonra su-etanol solüsyonu ile laboratuarda yıkanarak, etüvde $\quad 80 \quad{ }^{0} C^{\prime}$ de 24 saat bekletilerek kurutulmuştur. Kurutulmuş kabuklar değirmende öğütüldükten sonra, elekten geçirilmiş ve deneyde kullanıma hazır biyosorbent haline getirilmiştir. Deneylerde yüzey aktif madde ile modifiye edilmiş ve edilmemiş biyosorbentler kullanılmıştır. Modifiye edilmiş kabuklar önce $\mathrm{NaOH}$ ile muamele edilmiş daha sonra belli derişimlerde $(0,1,0,5,1$ ve $2 \mathrm{mM})$ yüzey aktif madde (HTAB) içeren solüsyonlarda çalkalamalı ortamda oda sıcaklığında bekletilerek hazırlanmıştır.

Bilecik'de bulunan bir Tekstil Fabrikası'ndan toz halde alınan Remazol Black B boyası stok solüsyonu, boyanın $\% 2$ (w/v) konsantrasyonunda distile suda çözülmesiyle hazırlanmıştır. $\mathrm{Bu}$ stok solüsyondan istenilen miktarlar distile su içeren ortamlara eklenerek deney düzenekleri hazırlanmıştır.

\section{Yüzey aktif madde solüsyonu hazırlanması}

Çalışmada kullanılan Hegzadesiltrimetil amonyum bromür (HTAB) (Şekil 1) isimli yüzey aktif madde katyonik özellikte bir molekül olup, molekül ağırlığı 364,46 g/mol'dür. Yüzey aktif maddenin stok solüsyonları $1 \mathrm{~g} / \mathrm{L}$ olacak şekilde yüzey aktif maddenin distile suda çözülmesiyle hazırlanarak, istenilen miktarlarda sulu ortamlara eklenmiştir.

\section{$\mathrm{CH}_{3} \mathrm{Br}^{-}$ $\mathrm{H}_{3} \mathrm{C}\left(\mathrm{H}_{2} \mathrm{C}\right)_{15}-\mathrm{N}^{+}-\mathrm{CH}_{3}$ $\mathrm{CH}_{3}$}

Şekil 1. Hegzadesiltrimetil amonyum bromür (HTAB)

\section{Biyosorpsiyon çalışmaları}

Kesikli ortamda yapılan deneyler $100 \mathrm{ml}$ erlenlerde $50 \mathrm{ml}$ boyalı $(50 \mathrm{mg} / \mathrm{L}$ derişiminde boya içeren) su ortamlarına modifiye edilmiş ve edilmemiş biyosorbentler eklenerek yapılmıştır. Hazırlanan biosorbentlerin boya giderimine farklı derişimlerdeki yüzey aktif madde modifikasyonunun $(0.1,0.5,1$ ve $2 \mathrm{mM})$, sıcaklığın $\left(25\right.$ ve $\left.50{ }^{\circ} \mathrm{C}\right), \mathrm{pH}^{\prime} ı n(1,3,5)$ ve temas süresinin $(0-$ 48 saat) etkisi test edilmiştir. Tüm deneylerde biyosorbent miktarı $1 \mathrm{~g} / \mathrm{L}$ olarak kullanılmıştır.

\section{Boya derişiminin belirlenmesi}

Deney süresi boyunca günlük $2 \mathrm{ml}$ örnekler alınıp, 10000 devir/dakika'da 15 dakika santrifüj edildikten sonra süpernatantlar $600 \mathrm{~nm}$ dalga boyunda spektrofotometrede analiz edilmiştir. Spektrofotometrik analizler laboratuvarda mevcut bulunan Agile-Spec model spektrofotometre ve santrifüj işlemi de Sigma D-37520 model santrifüj kullanılarak yapılmıştır. Biyosorpsiyonla yüzde boya giderimi ve biyokütlenin gramı başına alınan maksimum boya miktarı $\left(q_{m}\right)$ hesaplamaları için kullanılan formüller Eşitlik 1 (E. 1) ve Eşitlik 2 (E. 2)'de verilmiştir.

$\%$ Boya giderim $(B G)=\left(\left(A_{\circ}-A_{f}\right) / A_{\circ}\right) \times 100 E(1)$

$\mathrm{Bu}$ eşitlikte; $A_{o}$ : başlangıç boya konsantrasyonu (mg/L); Af: son boya konsantrasyonu (mg/L) $q_{m}=\left(\mathrm{C}_{\mathrm{o}}-\mathrm{C}_{\mathrm{f}}\right) / \mathrm{X}_{\mathrm{m}} \mathrm{E}(2)$

$\mathrm{Bu}$ eşitlikte; $q_{m}$ : kurutulmuş bir gram hücredeki maksimum boya miktarı (mg/g); $X_{m}$ : maksimum biyokütle miktarı $(\mathrm{g} / \mathrm{L})$; $\mathrm{C}_{\mathrm{o}}$ : başlangıç boya konsantrasyonu $(\mathrm{mg} / \mathrm{L}) \quad \mathrm{C}_{\mathrm{f}}$ : son boya konsantrasyonu (mg/L)

\section{Biyosorpsiyon izoterm ve kinetik hesaplamaları} Biyosorpsiyon izoterm modelleri biyosorbent ve biyosorbat arasındaki olası etkileşimler ve teorik maksimum biyosorpsiyon kapasitesi hakkında bilgi edinilmesini sağlar. Bu çalışmada, yaygın kullanıma sahip Freundlich ve 
Langmuir izoterm denklemleri kullanılmıştır. Freundlich izotermi (Freundlich, 1926) temel olarak heterojen yüzey enerjilerine sahip biyosorbentler üzerindeki biyosorpsiyonu tanımlar. Çalışmada kullanılan Langmuir ve Freundlich modellerine ait Non-lineer ve Lineer izoterm eşitlikleri Eşitlik (E) 3 ve 4'de verilmiştir. Non-lineer Freundlich: $q_{e}=\mathrm{K}_{\mathrm{F}} \mathrm{C}^{1 / n} \mathrm{E}(3)$ Lineer Freundlich: $\ln \left(q_{e}\right)=\ln \left(\mathrm{K}_{\mathrm{F}}\right)+1 / \mathrm{n} \ln \left(\mathrm{C}_{\mathrm{e}}\right) \mathrm{E}(4)$ $\mathrm{Bu}$ eşitlikte; $q_{e}$ :Birim biyokütle üzerinde tutulan birim madde ağırlığı $(\mathrm{mg} / \mathrm{g})$; $\mathrm{C}_{\mathrm{e}}$ : Biyosorplama olayı sonunda biyosorplanan maddenin denge halindeki konsantrasyonu (mg/L); $\mathrm{K}_{\mathrm{F}}=$ Freundlich biyosorpsiyon katsayısı; $\mathrm{n}=$ Karakteristik Freundlich izoterm sabiti Langmuir İotermindeki Langmuir biyosorpsiyon modeli ise tek tabakalı biyosorpsiyonu vurgulamaktadır (Langmuir, 1918). Hesaplamalarda kullanılan Non-lineer ve Lineer Langmuir izoterm eşitlikleri Eşitlik (E) 5 ve 6 'de verilmiştir.

Non-lineer Langmuir: $q_{e}: q_{m} \mathrm{~K}_{\mathrm{L}} \mathrm{C}_{\mathrm{e}} / 1+\mathrm{K}_{\mathrm{L}} \mathrm{C}_{\mathrm{e}} \mathrm{E}$ (5) Lineer Langmuir-1: $\mathrm{C}_{\mathrm{e}} / q_{e}=\left(1 / q_{m}\right) \mathrm{C}_{\mathrm{e}}+1 / \mathrm{K}_{\llcorner} q_{m} \mathrm{E}$ (6)Bu eşitlikte; $q_{e}$ : Dengede biosorbentin birim kütlesi başına biosorplanan madde miktarı (mg/g); $q_{m}$ : Biyosorpsiyon kapasitesi $(\mathrm{mg} / \mathrm{g}) ; \mathrm{Ce}_{\mathrm{e}}$ : Biyosorpsiyon olayı sonunda biyosorplanan maddenin denge halindeki konsantrasyonu (mg/L); KL: Enerji ile ilgili Langmuir biyosorpsiyon sabiti

Kinetik modeller ise kesikli biyosorpsiyon proseslerinde optimum koşulların tahmin edilmesine olanak sağlamaktadır. Bu çalışmada yaygın kullanılan yalancı birinci dereceden ve yalancı ikinci dereceden kinetik modellemeler kullanılmıştır. Non-lineer ve Lineer yalancı birinci dereceden model eşitlikleri Eşitlik (E) 7 ve 8 'de verilmiştir. Nonlineer Yalancı birinci dereceden model eşitliği: $q_{t}=q_{e}\left(1-\mathrm{e}^{-\mathrm{k} 1 \mathrm{t}}\right) \mathrm{E}$ (7)

Lineer Yalancı birinci dereceden model eşitliği: log $\left(q_{e}-q_{t}\right)=-\mathrm{k}_{1} / 2,303 \mathrm{t}+\log q_{e} \mathrm{E}(8)$

Non-lineer ve Lineer yalancı ikinci dereceden model eşitlikleri Eşitlik (E) 9 ve 10'da verilmiştir.

Non- lineer Yalancı ikinci dereceden model eşitliği: $q_{t}=\mathrm{k}_{2} q_{e}{ }^{2} \mathrm{t} / 1+\mathrm{k}_{2} q_{e} \mathrm{t} \mathrm{E}(9)$

Lineer Yalancı ikinci dereceden model eşitliği: $t /$ $=1 / \mathrm{k}_{2} q_{e}{ }^{2 \mathrm{t}}+\left(1 / q_{e}\right) \mathrm{t} \mathrm{E}(10)$
Bu eşitliklerde; $q_{t}$ : $\mathrm{t}$ zamanında adsorbentin gramı başına adsorplanan madde miktarı $(\mathrm{mg} / \mathrm{g})$; $\mathrm{t}$ : $\mathrm{t}$ zamanında adsorplanan miktar (dak); $\mathrm{k}_{1}$ : yalancı birinci dereceden hı sabiti $\left(\right.$ dak $\left.^{-1}\right) ; k_{2}$ : yalancı ikinci dereceden hız sabiti (g/mgdak)

\section{Bulgular ve Tartışma \\ Farklı derişimlerdeki yüzey aktif madde modifikasyonunun etkisi}

Çalışmada $0.1, \quad 0.5,1$ ve $2 \mathrm{mM}$ derişimlerindeki HTAB ile modifiye edilmiş yer fıstığı kabuğunun boya giderimi incelenmiştir. $\mathrm{Bu}$ deney serisinde ortam pH'sı 1'e ve sıcaklık ise 25 ${ }^{0} C^{\prime}$ ye ayarlanmıştır. Modifiye edilmemiş kabukların boya giderimi de test edilmiştir. Şekil 2'de farklı derişimlerdeki HTAB ile modifiye edilmiş ve edilmemiş yer fıstığının boya yüzde olarak hesaplanan biyosorpsiyon verileri gösterilmiştir.

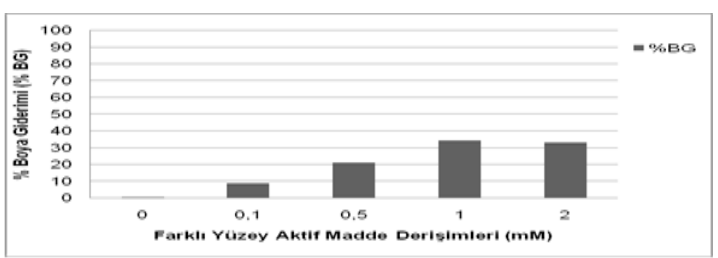

Şekil 2. Farklı derişimlerdeki HTAB ile modifiye edilmiş ve edilmemiş yer fıstığı kabuğu ile boya giderimi (\%BG); $\mathrm{pH}$ : 1 ; Sıcaklık: $25{ }^{\circ} \mathrm{C}$; Temas süresi: 24 saat

Şekil 2'de görüldüğü üzere, yüzey aktif madde ile modifiye edilmiş yer fıstığı kabukları modifiye edilmemiş olana göre daha iyi giderim gerçekleştirmiştir. Yüzey aktif madde ile modifiye zeolitin modifiye edilmemiş zeolite göre daha verimli boya adsorpsiyonu gerçekleştirdiği önceki yapılan bir çalışmada gösterilmiştir (Özdemir ve ark., 2009). Literatürde yüzey aktif madde ile modifiye farklı adsorbanların adsorpsiyon kapasitesi belirlenmiş ancak yüzey aktif madde ile modifiye edilmiş yer fıstığı ile ilgili herhangi bir çalışma bulunmamaktadır. Renk giderimi oranları karşılaştırıldığında 1 ve $2 \mathrm{mM}$ yüzey aktif madde ile modifiye edilmiş kabuk tarafından sırasıyla $34.33 \%$ ve $33.02 \%$ olarak belirlenmiştir (Şekil 2). Deneylerin devamı için 1 ve 2 mM HTAB ile modifiye biyosorbentlerin boya giderim yüzdeleri çok yakın olduğu için her iki biyosorbent daha ileri deneylerde kullanılmak üzere seçilmiştir. 


\section{Sıcaklık etkisi}

Ortam sıcaklığının boya giderimine etkisini araştırmak için 1 ve $2 \mathrm{mM}$ derişimlerindeki HTAB ile modifiye edilmiş yer fıstığı kabuğunun boya giderimi incelenmiştir. Ortam pH'sı 1 olarak ve sıcaklık $50{ }^{\circ} \mathrm{C}^{\prime}$ ye ayarlanmıştır. Modifiye edilmemiş yer fıstığı kabuğu ile de aynı koşullarda deneme yapılmıştır. Şekil 3 incelendiğinde, $50{ }^{\circ} \mathrm{C}$ ortam sıcaklığında $25{ }^{\circ} \mathrm{C}^{\prime}$ de (Şekil 2) olduğu gibi en iyi boya giderimini yüzey aktif madde ile modifiye edilmiş yer fıstığı kabuğu gerçekleştirmiştir. Modifiye edilmiş yer fıstığı kabuğu ile yüzde boya giderimi 1 ve $2 \mathrm{mM}$ için $25{ }^{\circ} \mathrm{C}^{\prime}$ de sırasıyla $34.33 \%$ ve $33.02 \%$ (Şekil 2) iken, $50{ }^{\circ} \mathrm{C}^{\prime}$ de sırasıyla $81.79 \%$ ve $81.02 \%$ olarak saptanmıştır (Şekil 3).

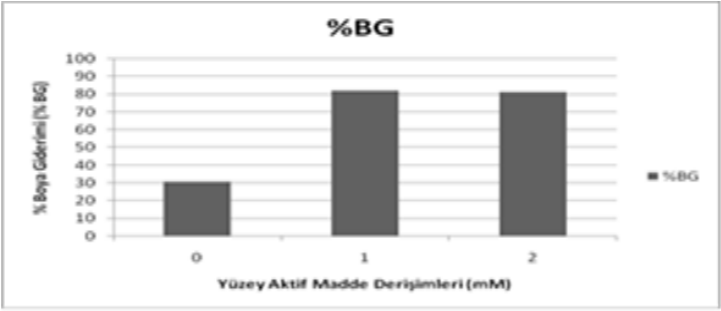

Şekil 3. Farklı derişimlerdeki HTAB ile modifiye edilmiş ve edilmemiş yer fıstığı kabuğu ile boya giderimi (\%BG); $\mathrm{pH}$ : 1; Sıcaklık: $50{ }^{\circ} \mathrm{C}$; Temas süresi: 24 saat

$\mathrm{Bu}$ bulgular sonucunda boya gideriminin gerçekleştiği en iyi sıcaklık $50{ }^{\circ} \mathrm{C}$ olarak belirlenmiş olup, biyosorpsiyon işlevinde sıcaklığın olumlu etkisi olduğu belirlenmiştir. Benzer şekilde Kılıç ve ark. (2014) yaptıkları bir çalışmada organik bir atık olan nohut samanının Metilen Blue isimli boyanın biyosorpsiyonla giderimini en iyi $50{ }^{\circ} \mathrm{C}^{\prime} \mathrm{de}$ gerçekleştirdiğini göstermiştir. Deng ve ark. (2007) yaptıkları çalışmada artan sıcaklığın biyosorpsiyon mekanizmasını arttırdığını ve bu tip mekanizmalarda endotermik reaksiyonların gerçekleştiğini rapor etmişlerdir.

\section{pH etkisi}

Farklı pH değerlerinin (1, 3 ve 5 gibi) biyosorpsiyona etkisi Şekil 4'de verilmiş olup, en iyi giderimin düşük (1 ve 3 gibi) $\mathrm{pH}^{\prime}$ larda gerçekleştiği görülmüştür. Ortam pH'sı biyosorpsiyon için önemli bir parametre olup, ortamdaki moleküllerin yüzey yüklerini etkilemektedir. Yüzey aktif maddelerin boya giderimine etkisi üzerine yapılan bir çalışmada düşük $\mathrm{pH}^{\prime}$ larda katyonik yüzey aktif maddenin mikrobiyal anyonik boya giderimini artırdığı gösterilmiştir (Gül ve Dönmez, 2012). Bu çalışmada ise farklı olarak yüzey aktif madde ile modifiye biosorbent kullanılmış olup, $2 \mathrm{mM}$ katiyonik yüzey aktif madde ile modifiye biyosorbentin anyonik boya biyosorpsiyonunu en iyi $\mathrm{pH} \quad 3$ 'de \%97.48 olarak gerçekleştirdiği görülmüştür (Şekil 4).

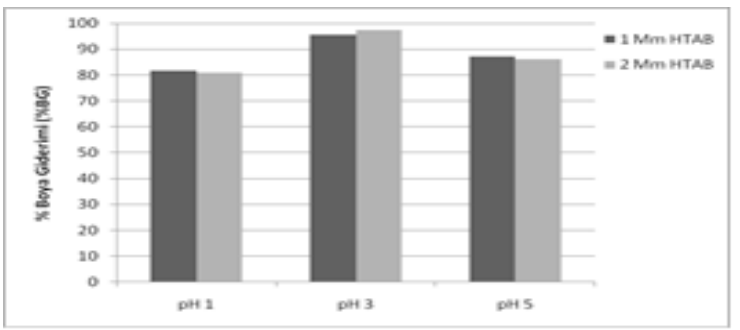

Şekil 4. Farklı pH'lardaki 1 ve $2 \mathrm{mM}$ derişimlerdeki HTAB ile modifiye edilmiş yer fıstığı kabuğu ile boya giderimi (\%BG); Sıcaklık: $50{ }^{\circ} \mathrm{C}$; Temas süresi: 24 saat

\section{Temas Süresinin Etkisi}

Biyosorpsiyona temas süresinin etkisinin belirlenmesi amacıyla belirlenen optimal koşullar altında farklı sürelerdeki boya konsantrasyonları belirlenmiş olup, sonuçlar şekil 5'de verilmiştir. Temas süresi etkisinin araştırıldığı deneyler sonunda 24 . ve 48 . saatler sonunda boya giderimi sırasıyla \%97.48 ve \%97.10 olarak belirlenmiş olup, 24. saatten sonra boya gideriminde belirgin bir değişiklik olmadığı görülmüştür. En iyi giderim için belirlenen temas süresi 24 saat olarak belirlenmiştir.

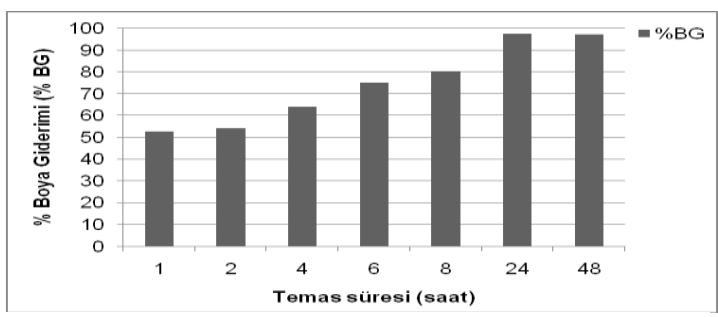

Şekil 5. Farklı temas sürelerindeki 2 mM HTAB ile modifiye yer fıstığı kabuğu ile boya giderimi (\%BG); pH: 3; Sıcaklık: $50{ }^{\circ} \mathrm{C}$

Yapılan biyosorpsiyon deneylerinin sonuçlarına göre en iyi boya giderimi yapan biyosorbent $2 \mathrm{mM}$ HTAB yüzey aktif maddesi ile 
modifiye edilmiş yer fıstığı olup, $50 \mathrm{mg} / \mathrm{L}$ boya derişimi içeren deney düzeneklerinde en iyi boya gideriminin gerçekleştiği optimal koşullar pH 3'de, $50{ }^{\circ} \mathrm{C}$ sıcaklıkta ve 24 saatlik temas süresi şeklinde belirlenmiştir. Bu koşullar altında modifiye yer fıstığı kabuğu atığından oluşmuş biyosorbentin maksimum boya biyosorpsiyonu kapasitesi $\left(q_{\mathrm{m}}\right)$ ise $28,04 \mathrm{mg} / \mathrm{g}$ olarak hesaplanmıştır.

\section{Biyosorpsiyon izoterm ve kinetik hesaplamaları}

Çalışma sonuçlarında belirlenen optimal koşullardaki veriler kullanılarak izoterm ve kinetik modelleme hesaplamaları yapılmıştır. Freundlich ve Langmuir izotermlerinin modelleme hesaplarından elde edilen değerler Çizelge 1 'de verilmiştir.

Çizelge 1'e göre, RBB boyasının modifiye atık yer fıstığı kabuğundan elde edilen biyosorbent üzerine biyosorpsiyonununda korelasyon değeri Freundlich ve Langmuir izoterm modelleri için sırasıyla 0.890 ve 0.912 olarak hesaplanmıştır. Langmuir izotermine ait korelasyon değeri daha yükesk olduğu için Langmuir izotermine uyum olduğu kabul edilir. Langmuir izotermine uyum biyosorbent yüzeyinin homojen olduğuna ve yüzeyin tek tabaka ile kaplandığına işaret etmektedir. RBB tekstil boyasının modifiye atık yer fıstığı kabuğundan elde edilen biyosorbent üzerine biyosorpsiyonu için kinetik hesaplamalarda yalancı birinci dereceden (Pseudo first-order) ve yalancı ikinci dereceden (Pseudo second-order) modelleri kullanılmıştır. Kinetik hesaplamalardan elde edilen veriler Çizelge 2 'de verimiştir.

Çizelge 1. Biosorpsiyon izoterm parametereleri ( $q_{\mathrm{m}}$ : en iyi boya alım kapasitesi, $\mathrm{K}_{\mathrm{L}}$ : Langmuir izoterm sabiti; $\mathrm{K}_{\mathrm{F}}$ : Freundlich izoterm sabiti; RBB: Remazol Black B; 2 mM HTAB ile modifiye yer fıstığı kabuğu)

\begin{tabular}{cccccc}
\hline \multicolumn{3}{c}{ Langmuir } & \multicolumn{3}{c}{ Freundlich } \\
\hline$q_{\max }$ & $\mathrm{K} \mathrm{R}^{2}$ & $\mathrm{~K} F$ & $1 / \mathrm{n}$ & $\mathrm{R}^{2}$ \\
$(\mathrm{mg} / \mathrm{g})$ & $(\mathrm{L} / \mathrm{mg})$ & & $(\mathrm{L} / \mathrm{mg})$ & & \\
\hline 21.74 & 0.051 & 0.912 & 814.85 & 0.793 & 0.890 \\
\hline
\end{tabular}

Çizelge 2 incelendiğinde modifiye atık yer fıstığı kabuğundan oluşmuş biyosorbent üzerine RBB boyasının biyosorpsiyonuna ait yalancı birinci dereceden kinetiğine ait korelasyon değeri, $R^{2}=$ 0.815 olarak belirlenmiştir. Bu yüksek korelasyon değerine rağmen denklemden elde edilen teorik $q_{t}$ değeri ile deneysel olarak bulunan $q_{t}$ değeri birbirleriyle uyum sağlamamaktadır. Bu nedenle biyosorpsiyon yalancı birinci dereceden kinetiğe uymamaktadır. Yalancı ikinci dereceden kinetiğine ait korelasyon değeri, $\mathrm{R}^{2}=0.970$ olarak belirlenmiş olup, deneysel qt ile teorik qt değerleri ise birbirine yakın olarak bulunmuştur. $\mathrm{Bu}$ nedenle RBB'nin modifiye atık yer fistığı kabuğu üzerine biyosorpsiyonu yalancı ikinci dereceden kinetik modele uymaktadır. Biyosorpsiyonun yalancı ikinci dereceden kinetik modele uyması, biyosorbent ile boya arasında kimyasal bir aktivasyon olacağına işaret etmektedir.

Çizelge 2. Biosorpsiyon kinetik parametereler

\begin{tabular}{llll}
\hline \multicolumn{4}{l}{ Yalancı Birinci Dereceden } \\
\hline $\boldsymbol{q}_{t}$ & $\boldsymbol{q}_{\boldsymbol{t} \text { (deneysel) }}$ & $\mathbf{k}_{\mathbf{1}}$ & $\mathbf{R}^{\mathbf{2}}$ \\
14.15 & 84.13 & 0.0069 & 0.81 \\
\hline \multicolumn{2}{l}{ Yalancı ikinci Dereceden } & & \\
\hline $\boldsymbol{q}_{\boldsymbol{t}}$ & $\boldsymbol{q}_{\boldsymbol{t} \text { (deneysel) }}$ & $\mathbf{k}_{\mathbf{2}}$ & $\mathbf{R}^{\mathbf{2}}$ \\
66.67 & 84.13 & 0.00047 & 0.97 \\
\hline
\end{tabular}

\section{Sonuç ve Öneriler}

$\mathrm{Bu}$ çalışmada atık olan yer fıstığı kabuklarının boya gideriminde kullanılabilirliği araştırılmıştır. Boya biyosorpsiyonunu teşvik etmek amacıyla atık biyosorbent yüzey aktif madde ile modifiye edilmiştir. Modifiye biyosorbentin biyosorpsiyon yüzdesinin modifiye olmayana göre 3 kat arttığı tespit edilmiştir. Bu araştırmanın sonuçları yüzey aktif madde ile modifiye yer fıstığı kabuklarının tekstil boyası arıtımı için ucuz ve etkin bir biyosorbent olarak kullanılabileceğini desteklemektedir. Bu bağlamda yer fıstığı üretimi ve tüketimi sonucunda oluşan atıkların tekstil endüstrisi atık sularının artımında biyosorbent şeklinde kullanımının bu atıkların bertarafı için alternatif bir yol olabileceği önerilmektedir.

\section{Kaynaklar}

Arslan Alaton, i. ve Teksoy, S. 2007. Acid Dyebath Effluent Pretreatment Using Fenton's Reagent: Process Optimization, Reaction Kinetics and Effects on Acute Toxicity. Dyes and Pigments, 73: 31-39.

Bagha, A.R.T., Bahrami, H., Movassagh, B., Arami, M. ve Menger, F.M. 2007. Interactions of 
gemini cationic surfactants with anionic azo dyes and their inhibited effects on dyeability of cotton fabric. Dyes and Pigments, 72: 331-338.

Bilen, S. ve Yıldırım, E. 2017. Topraktaki Ağır Metallerin AbsorbsiyonuÜzerine Bakteri İzolatlarının Etkisi. Türk Tarım ve Doğa Bilimleri Dergisi, 4(3): 355-365.

Bilir, M. 2009. Yer Fıstığı Kabuğundan Üretilen Poliüretan Tipi Köpük ile Safranin ve Remazol Brillant Blue R'nin Adsorpsiyonunun İncelenmesi. Yüksek Lisans Tezi, Kilis 7 Aralık Üniversitesi, Kilis, Türkiye.

Chaleshtori, A.A.N., Meghadddam, F.M., Sadeghi, M.M., Rahimi, R.R., Hemati, S. ve Ahmadi, A.A. 2017. Removal of Acid Red 18 (AzoDye) from Aqueous Solution by Adsorption onto Activated Charcoal Prepared from Almond Shell. Journal of Environmental Science and Management, 20:2

Deng, L., Su, Y., Su, H., Wang, X. ve Zhu, X. 2007. Sorption and esorption of lead(II) from wastewater by Green Algea CladopHora fascicularis. Journal of Hazardous Materials, 143: 220-225.

Freundlich, H. 1926. Colloid and Capillary Chemistry. Methuen, London.

Gomez, V., Larrenchi, M.S. ve Callao, M.P. 2007. Kinetik and Adsorption Study of Acid Dye Removal Using Activated Carbon. Chemosphere, 69: 1151-1158.

Gül, Ü.D. 2019. A Green Approach For The Treatment of Dye And Surfactant Contaminated İndustrial Wastewater. Braz. J. Biol. [online]. In press., http://dx.doi.org/10.1590/15196984.21806.

Gül, Ü.D. ve Dönmez, G. 2012. Comparison the dye removal activity of systems contained surfactants and fungus. Journal of Chilean Chemical Society, 57: 170-1173.

Kadiroğlu A. "Yerfıstığı Yetiştiriciliği". http:// www.batem.gov.tr (23.05.2014).

Kartal, Ç. ve Akbaş, H. 2005. Study on the Interaction of Anionic Dye-Nonionic Surfactants in Mixture of Anionic and Nonionic Surfactants by Absorption Spectroscopy. Dyes Pigments, 65: 191-195.

Kılıç, M., Çepelioğullar, Ö., Özsin, G., Uzun, B.B. ve
Pütün, A.E. 2014. Nohut samanı tarla atığının sulu çözeltilerden metilen mavisi gideriminde düşük maliyetli biyosorbent olarak değerlendirilmesi. Gazi Üniversitesi Mühendislik Mimarlık Fakültesi Dergisi, 29(4): 717-726.

Langmuir, L. 1918. The adsorption of gases on plane surfaces of glass, mica and platinum. Journal of American Chemical Society, 40:1361-1403.

Manu, B. ve Chaudhari, S. 2002. Anaerobic Decolorisation of Simulated Textile Wastewater containing Azo Dyes. Bioresource Technology, 82: 225-33.

Mass, R., Chaudhari, S. 2005. Adsorption and biological decolorization of azo dye Reactive Red-2 in semicontinuous anaerobic reactors. Process Biochem, 40: 699-705.

Özcan, A. ve Özcan, A.S. 2005. Adsorption of Acid Red 57 from aqueous solutions onto surfactant-modified sepiolite. Jornal of Hazardous Materials, 125: 252- 259.

Özdemir, Ö., Turan, M., Turan, A., Faki, A. ve Engin, A. 2009. Feasibility analiysis of color removal from textile dyeing in a fixed-bed column system by surfactant-modified zeolite (SMZ). Journal of Hazardous Materials, 166: 647-654.

Seesuriyachan, P., Takenaka, S., Kuntiya, A., Klayraung, S., Murakami, S., Aoki, K. 2007. Metabolism of azo dyes by Lactobacillus casei TISTR 1500 and effects of various factors on decolorization. Water research, 41: 985-992.

Şahin, G. 2014. Türkiye'de Yerfıstığı (Arachis hypogaea L.) Yetiştiriciliği ve Bir Coğrafi Iş̧aret Olarak Osmaniye Yerfıstığı. Gaziantep University Journal of Social Sciences, 13(3):619-644.

Taşar, Ş., Kaya, F., Özer, A. 2015. Yerfıstığı Kabuğunun Farklı İzotermal Şartlarda Pirolizi ve Kinetik Parametrelerin Belirlenmesi Üzerine Bir Çalışma. Pamukkale Üniversitesi Mühendislik Bilim Dergisi, 21(7): 306-313. 